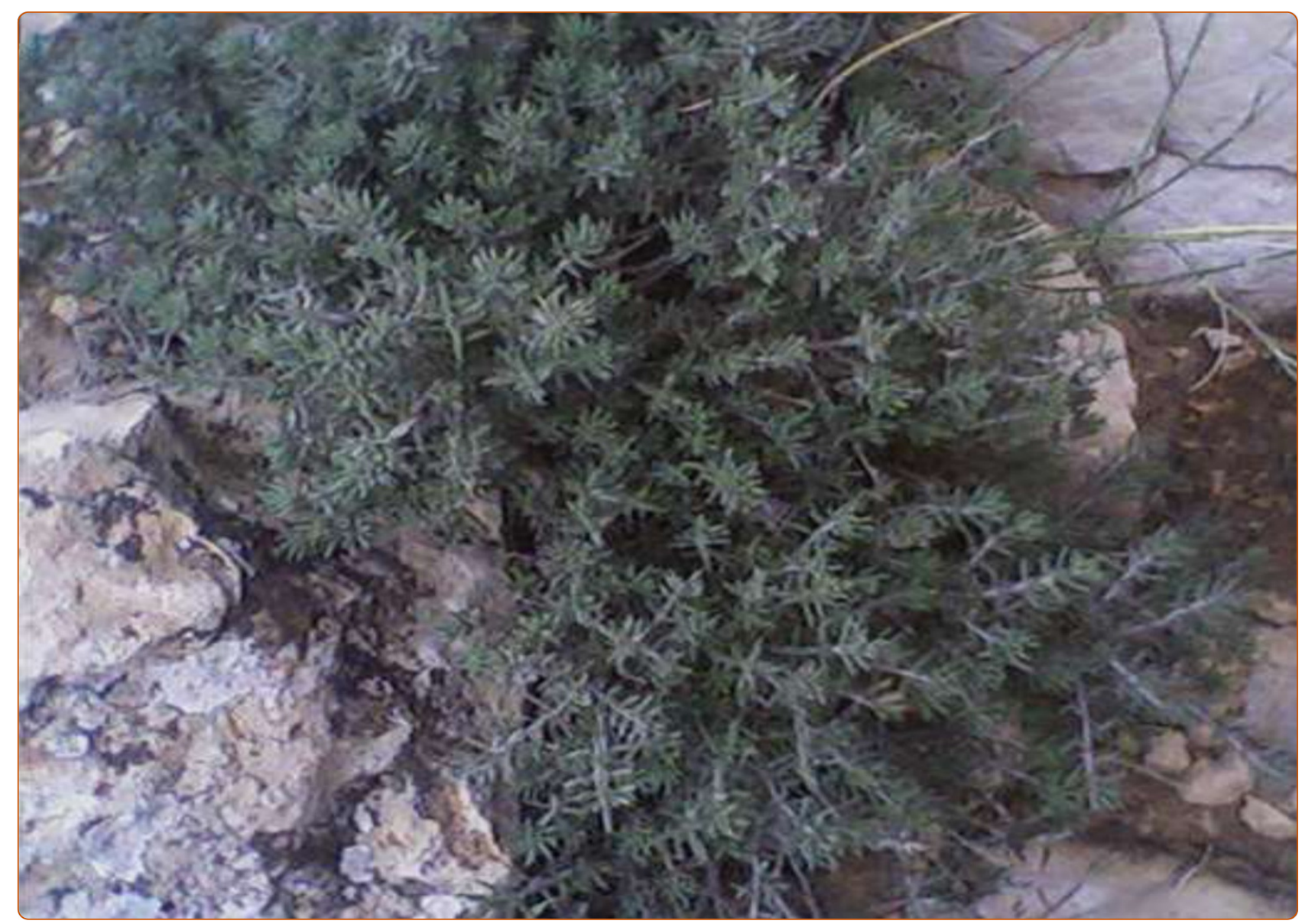

Effects of Thymus hirtus sp. algeriensis Boiss. et Reut. (Lamiaceae) essential oil on healing gastric ulcers according to sex

Guesmi et al. 


\title{
Effects of Thymus hirtus sp. algeriensis Boiss. et Reut. (Lamiaceae) essential oil on healing gastric ulcers according to sex
}

Fatma Guesmi ${ }^{1 *}$, Manel Ben Ali ${ }^{2}$, Taha Barkaoui ${ }^{1}$, Wiem Tahri ${ }^{1}$, Mondher Mejri ${ }^{3}$, Mossadok Ben-Attia ${ }^{2}$, Houda Bellamine ${ }^{4}$ and Ahmed Landoulsi ${ }^{1}$

\begin{abstract}
Background: Thymus algeriensis Boiss. et Reut. (Lamiaceae), popularly known as "mougecha" or "mazoukcha" is prolific in Mediterranean regions, mostly in North Africa, and is used in folk medicine to treat of stomach diseases.

Methods: In this study, animals were induced with gastric ulcers using $\mathrm{HCl} /$ ethanol $(0.3 \mathrm{M} \mathrm{HCl} / 60 \%$ ethanol) and treated orally with essential oil of Thymus algeriensis (EOTa) in various doses ranging from $54 \mathrm{mg} / \mathrm{kg}$ body weight to $180 \mathrm{mg} / \mathrm{kg}$ body weight.

Result: The dose found to be effective was $180 \mathrm{mg} / \mathrm{kg}$ body weight, since this dose brought about a maximum reduction in lesion index in female rats. In gastric tissues, levels of total glutathiones (GSH, GST and GPx) and thiobarbituric acid reactive substances (TBARS) were evaluated. The activities of the antioxidant enzymes, catalase (CAT) and superoxide dismutase (SOD) were measured. Histopathological changes were observed using a cross section of gastric tissue. Chemical analysis revealed the presence of 13 components accounting for $77.7 \%$ of the essential oil from dried leaves. Oral administration of EOTa $(54,117$ and $180 \mathrm{ml} / \mathrm{kg}$ ) inhibited HCl/ethanol-induced ulcers. Lesion index was significantly reduced in ulcer induced animals treated with EOTa ( $\mathrm{HCl} /$ ethanol + EOTa) compared to those ulcerated with $\mathrm{HCl} /$ ethanol but with no treatment given. Females showed a greater resistance to ulcers and gastric lesions occurred less often than in males. GSH, pH, enzymic antioxidants, and adherent mucus content were all significantly increased.
\end{abstract}

Conclusion: From the data presented in this study, it can be concluded that male rats are more sensitive to gastric ulcers induced by $\mathrm{HCl} /$ ethanol than females.

Keywords: Thymus algeriensis, Gastric ulcers, HCl/ethanol, Antioxidant enzymes

\section{Background}

A peptic ulcer is an excoriated area of the gastric or duodenal mucosa caused by gastric juice action. It is both a chronic and recurrent disease, and the most predominant of the gastrointestinal diseases [1]. Potentially injurious agents such as acid, pepsin, bile acids, food ingredients, bacterial products and drugs have been implicated in the pathogenesis of gastric ulcers, including increased gastric acid and pepsin secretion, decreased gastric blood flow, suppression of endogenous generation of prostaglandins,

\footnotetext{
* Correspondence: fguesmi77@yahoo.com

'Laboratory of Biochemistry and Molecular Biology, Faculty of Science of Bizerte, Bizerte, Tunisia

Full list of author information is available at the end of the article
}

inhibition of mucosal growth and alteration of gastric mobility [2]. Some evidence suggests that reactive oxygen species play a role in the etiology and pathogenesis of digestive system disorders such as gastrointestinal inflammation and gastric ulcers [3].

ROS could either directly disrupt the mitochondrial membrane that subsequently leads to the release of cytochrome $\mathrm{C}$ which becomes a part of the apoptosome complex, or it could lead to membrane rupture of lysosomes in an additive way resulting in the release of cathepsins which activate caspase and an apoptosis cascade, finally leading to cell death via apoptosis. On the contrary, cells protect themselves against the destructive effects of ROS by scavenging them through the enzyme defense system, 
or through the antioxidant activities of dietary compounds [4]. After exposure to oxidative stress, the defense mechanisms including an enzymatic system such as superoxide dismutase (SOD), catalase (CAT), glutathione peroxidase (GPx) and non-enzymatic system such as glutathione (GSH), $\beta$-carotene (vitamin A), ascorbic acid (vitamin C) and $\alpha$-tocopherol (vitamin E) are involved $[5,6]$.

The stomach can activate many gastroprotective mechanisms to prevent injury from noxious agents. Of these defensive factors, several studies have recently demonstrated that the gastric mucus offers protection $[7,8]$. When it is overwhelmed or breaks down due to disease, the second line of defense includes intracellular acid neutralization, rapid epithelial repair and maintenance, and redistribution of gastric vasculature [9].

The current medicinal treatment of peptic ulcers is generally based on inhibition of gastric acid secretion by $\mathrm{H} 2-$ blockers, omeprazole and antimuscarinics, as well as on acid-independent therapy provided by sucralfate and bismuth. The first proton pump inhibitor (PPI) used clinically was omeprazole (2-[[3,5-dimethyl-4-methoxypyridin-2- yl] methylsul ${ }^{\circledR}$ nyl]-5-methoxy-1H-benzimidazole). Compounds in this class are acid-activated prodrugs [10]. In cases of Helicobacter pylori infection, antibiotics are used. Obviously, drugs endowed with antisecretory activity coupled with gastroprotective effects could be a promising approach for successful treatment of peptic gastric ulcers because of the potential complementary effects of therapeutic modalities acting via different mechanisms [11].

It has been suggested that experimental ulcers induced by ethanol administration cause more severe gastric erosion in male rats than in females [12]. The female sex has a greater resistance to stress and thus, gastrointestinal lesions happen less often than in the male sex [13]. Males have a well-known risk of stroke and, in most epidemiological series, stroke occurs more frequently in men than women. This sexually dimorphic disease pattern remains apparent until an age well beyond the menopausal years [14]. The development of new antiulcer drugs and the search for novel molecules has therefore been extended to herbal drugs that offer better protection and decreased relapse. Medicinal plants provide an effective and safer way to manage disease. Many medicinal plants exhibit antiulcer activity and were found useful in the treatment of peptic ulcers [15].

Generally, antiulcerogenic compounds obtained from plants exert their effects either by stimulating the protective factors of gastric mucosa due to increased synthesis of prostaglandins, by stimulating the secretion of mucus and bicarbonate through inhibition of acid secretion by interacting with different receptors, or by regulating enzymes or hormones involved in the secretory process [16].

Herbal medicines have now triumphed as a diverse popular therapy and are emerging as an alternative treatment to the synthetic drugs available $[17,18]$. The latest trends have shown an increasing demand for phytodrugs and some medicinal herbs have been proven to have antiulcer activity. This alone is an important reason to investigate the antiulcer effects of medicinal plants through traditional use in preventing gastric disease. Essential oils are an important part of traditional pharmacopoeia in many countries and have been successfully used for gastroprotection and healing ulcers. Essential oils are complex mixtures made up of many single compounds chemically derived from terpenes and their oxygenated compounds. These constituents contribute to the antifungal, antiviral and antioxidant effects $[19,20]$. Of those plants known for their medicinal value, the plants of the genus thymus belonging to the Lamiaceae family (common name: Mougecha or Mazoukcha) are very important for their therapeutic potential. Thymus algeriensis, which is commonly found throughout North Africa, has been widely used in traditional medicine as an antiseptic and antispasmodic. Furthermore, this plant also has widespread use in folk medicine against illnesses of the digestive tube and for antiabortion [21]. Recently, $T$. algeriensis essential oil was found to possess an interesting inhibitory activity towards the angiotensin I-converting enzyme suggesting the potential of this plant as an antihypertensive agent [22].

Thus, the present study intends to explore the ulceroprotective and antioxidant activity of the essential oil of this species on $\mathrm{HCl} /$ ethanol- induced ulcers in rats. Our aim was to investigate whether sex had an influence on healing changes in the gastric acid secretion and blood flow at the margin of the ulcer.

\section{Material and methods}

\section{Plant material}

The aerial part of Thymus sp. algeriensis was collected on Mount Orbata (Jbel Orbata) near Zannouch, Gafsa, Tunisia. No specific permission was required to take plants from these locations and the field studies did not involve endangered or protected species. The plant material was authenticated by Mr. Hamdi Lazhar, Engineer and Director of Bouhedma Natural Park and the voucher specimens were deposited in the Herbarium of the National Institute of Agronomy of Tunisia (INAT) for future reference.

\section{Extraction and chromatographic analysis of the essential oil of Thymus algeriensis (EOTa)}

The essential oil from dried powdered Thymus algeriensis aerial parts was isolated by steam distillation in a Clevenger-type apparatus according to Procedure III of the Yugoslav Pharmacopoeia IV [23]. Essential oil yield was $2.3 \%(w / w)$. Freshly isolated essential oil was a yellow liquid with an intense, necrotic odor. 
Samples of $1 \mu \mathrm{l}$ (dilution in hexane 10\%) were subjected to analysis by GC-MS. GC analysis was performed on a model 7890 A (series II) gas chromatograph, with a flame ionization detector (FID) and a split ratio of 1:50 using a fused silica capillary column, HP5-MS (30 m × $250 \mu \mathrm{m}$ i.d., $0.25 \mu \mathrm{m}$ film thickness). Injector or detector temperature for each analysis was about $250^{\circ} \mathrm{C}$, and the carrier gas was helium with a flow rate of $0.8 \mathrm{ml} / \mathrm{min}$. Peak areas were measured by electronic integration, and relative amounts of the individual components were based on the peak areas. GC-MS was carried out on an Agilent model 5975 C mass spectrometer operating at ionizing energy mode at $70 \mathrm{eV}$, combined with the GC described above.

\section{Preparation of drug solution}

One hundred grams of the air dried AERIAL PART OF Thymus algeriensis were steam distilled for $6 \mathrm{~h}$ to prepare the appropriate stock solution of the drug, i.e. $54 \mathrm{mg} / \mathrm{ml}$, $117 \mathrm{mg} / \mathrm{ml}$ and $180 \mathrm{mg} / \mathrm{ml}$. Complete analyses of the samples are in progress. For the pharmacological tests carried out here, the complete essential oil was emulsified in vehicle $(0.1 \%$ Tween 80 aqueous solution) before administering it to the animals. The doses were administered orally by selecting the appropriate concentration of the stock solution. Omeparazole was dissolved in vehicle and given orally to the reference control group (6 rats) in doses of $20 \mathrm{mg} / \mathrm{kg}$ body weight.

\section{Experimental protocol}

A total of 54 Adult male and female Wistar rats (weighing 150 to $180 \mathrm{~g}$ and housed six per cage) were obtained from the Animal Laboratory of the Pasteur Institute of Tunis, Tunisia (Ethics No. LNSP/Pro 152012). They were provided with food and water ad libitum and were housed in polypropylene cages under pathogen free, uniform conditions of light and dark cycles (12 h each). Temperature was kept constant at $25^{\circ} \mathrm{C} \pm 2{ }^{\circ} \mathrm{C}$. Rats were randomly divided into 9 groups ( $n=6 /$ group) and made to fast for $24 \mathrm{~h}$ with free access to water prior to the experiment. Group 1 (Female rats) and Group 2 (Male rats): the animals were given an oral dose of $0.5 \mathrm{ml}$ of vehicle $(0.1 \%$ tween-80 aqueous solution) (Table 1 ); $80 \mathrm{mg} / \mathrm{ml}$ of a solution containing $0.3 \mathrm{M} \mathrm{HCl} / 60 \%$ ethanol $(\mathrm{HCl} / \mathrm{ethanol})$ to induce gastric ulcers was administered overnight to fasting rats. Group 3: (Standard drug treated group): rats were treated with omeprazole $(20 \mathrm{mg} / \mathrm{kg} / \mathrm{p} . \mathrm{o})$ one hour before they were subjected to the $\mathrm{HCl} /$ ethanol treatment. Groups 4, 5, and 6 received EOTa $(54,117$ and $180 \mathrm{ml} / \mathrm{kg}$, p.o treated female rats) and Groups 7, 8 and 9 received EOTa $(54,117$ and $180 \mathrm{ml} / \mathrm{kg}$, p.o treated male rats) treated with essential oil of T.algeriensis dissolved in a $0.1 \%$ tween $80 \%$ aqueous solution. $\mathrm{HCl} /$ ethanol $(80 \mathrm{mg} / \mathrm{ml})$ was administered after one hour to induce ulcers. Animals were sacrificed $1 \mathrm{~h}$ after administering $\mathrm{HCl} /$ ethanol and the stomachs were excised and inflated by saline injection $(2 \mathrm{ml})$ to determine the ulcer index. All rats were sacrificed under ether anesthesia, and all efforts were made to minimize suffering. Throughout the experiments, all animals were treated humanely. All experiments were performed in the morning and in accordance with the guidelines provided by the Institutional Animal Ethics Committee. The gastroprotective effect of EOTa was assessed from lipid peroxide (LPO), reduced glutathione (GSH), and activities of enzymic antioxidantssuper oxide dismutase (SOD), catalase (CAT), glutathione peroxidase (GPx), and glutathione- $S$-transferase (GST) in gastric mucosa.

\section{Macroscopic gastric lesion evaluation}

After washing with normal saline, gastric lesions were quantified and ulcers were scored according to the method used by Dashputre and Naikwade [24]. The ulcer scores were as follows:

.0: normal colored stomach.

.0.5: red coloration.

.1: spot ulcers.

.1.5: haemorrhagic streak.

.2: deep ulcers.

.3: perforation.

Table 1 The experimental design and specifications

\begin{tabular}{llll}
\hline Groups number & Description & Pre-treatment & Treatment \\
\hline Group 1 & Control (female rats) & $0.5 \mathrm{ml}$ of vehicle $(0.1 \%$ tween-80 aqueous solution) & $(80 \mathrm{mg} / \mathrm{ml}) \mathrm{HCl} / \mathrm{ethanol}$ \\
Group 2 & Control (male rats) & $0.5 \mathrm{ml}$ of vehicle $(0.1 \%$ tween-80 aqueous solution) & $(80 \mathrm{mg} / \mathrm{ml}) \mathrm{HCl} / \mathrm{ethanol}$ \\
Group 3 & Reference control & Omeprazole $20 \mathrm{mg} / \mathrm{kg}$ & $(80 \mathrm{mg} / \mathrm{ml}) \mathrm{HCl} / \mathrm{ethanol}$ \\
Group 4 & Experimental group 1 (male rats) & Complex $54 \mathrm{mg} / \mathrm{kg}$ & $(80 \mathrm{mg} / \mathrm{ml}) \mathrm{HCl} / \mathrm{ethanol}$ \\
Group 5 & Experimental group 2 (male rats) & Complex $117 \mathrm{mg} / \mathrm{kg}$ & $(80 \mathrm{mg} / \mathrm{ml}) \mathrm{HCl} / \mathrm{ethanol}$ \\
Group 6 & Experimental group 3 (male rats) & Complex $180 \mathrm{mg} / \mathrm{kg}$ & $(80 \mathrm{mg} / \mathrm{ml}) \mathrm{HCl} / \mathrm{ethanol}$ \\
Group 7 & Experimental group 4 (female rats) & Complex $54 \mathrm{mg} / \mathrm{kg}$ & $(80 \mathrm{mg} / \mathrm{ml}) \mathrm{HCl} / \mathrm{ethanol}$ \\
Group 8 & Experimental group 5 (female rats) & Complex $117 \mathrm{mg} / \mathrm{kg}$ & $(80 \mathrm{mg} / \mathrm{ml}) \mathrm{HCl} / \mathrm{ethanol}$ \\
Group 9 & Experimental group 6 (female rats) & Complex $180 \mathrm{mg} / \mathrm{kg}$ & $(80 \mathrm{mg} / \mathrm{ml}) \mathrm{HCl} / \mathrm{ethanol}$ \\
\hline
\end{tabular}


The mean ulcer score for each animal was expressed as an ulcer index. The percentage of ulcer protection was determined as follows:

The ulcer index score for each animal was expressed as an ulcer index. The percentage of ulcer protection was determined as follows:

The ulcer index (UI) was measured using following formula:

$\mathrm{UI}=\mathrm{UN}+\mathrm{US}+\mathrm{UP} \times 10^{-1}$ Where, $\mathrm{UI}=$ Ulcer Index; $\mathrm{UN}=$ Average number of ulcers per animal;

US = Average severity score; UP = Percentage of animals with ulcers.

The mean ulcer score for each animal was expressed as an ulcer index. The percentage of ulcer inhibition was determined as follows:

$$
\% \text { inhibition of Ulceration }=\frac{\left(\text { Ulcer index }_{\text {Control }}-\text { Ulcer index }_{\text {Test }}\right)}{\left(\text { Ulcer index }_{\text {Control }}\right)} \times 100
$$

\section{Histology of gastric lesions}

Samples of gastric tissue were fixed in 10\% buffered formalin. The stomach was sectioned at $5 \mu \mathrm{m}$ and stained with Hematoxylin Eosin for histological assessment.

\section{Assessment of oxidative stress in tissue}

In order to determine the effect of EOTa on oxidative stress induced in the $\mathrm{HCl} /$ ethanol model, the levels of GSH, TBARS and activities of SOD, CAT, GPx and GST were measured in gastric tissue.

\section{Preparation of homogenate}

The stomachs were weighed and homogenized in a buffer solution of potassium phosphate ( $\mathrm{pH}$ 7.4) and centrifuged at 3,000 rpm/15 min. The supernatant was used for the enzymatic and MDA assays.

\section{Estimation of protein}

Protein content of the gastric tissue was determined by the Folin Lowry Method using a bovine serum albumin as a standard [25].

\section{Determination of total glutathione (GSH)}

Reduced glutathione was estimated by the method indicated by Sedlak and Lindsay [26]. The homogenate was immediately precipitated with $0.1 \mathrm{ml}$ of $25 \%$ trichloroacetic acid, and the precipitate was removed by centrifugation at $4200 \mathrm{rpm}$ for $40 \mathrm{~min}$ at $4^{\circ} \mathrm{C}$. The precipitated tissue homogenate was treated with 5,5'-dithiobis(2- nitrobenzoic acid) (DTNB) reagent. A standard calibration curve was prepared using reduced glutathione $(\mathrm{GSH})$. Absorbance was measured at $412 \mathrm{~nm}$ using a spectrophotometer. The amount of glutathione was expressed as $\mu \mathrm{mol} / \mathrm{mg}$ protein.

\section{Estimation of SOD antioxidant enzyme}

Enzyme activity was assayed by following the inhibition of pyrogallol auto-oxidation [27]. Pyrogallol (24 mmol/L) was prepared in $10 \mathrm{mmol} / \mathrm{L} \mathrm{HCl}$ and stored at $4^{\circ} \mathrm{C}$. CAT $30 \mu \mathrm{mol} / \mathrm{L}$ stock solution was made in an alkaline buffer ( $\mathrm{pH}$ 9.0). Aliquots of supernatant were added to a Tris$\mathrm{HCl}$ buffer containing $12.5 \mu \mathrm{l}$ of pyrogallol and $12.5 \mu \mathrm{L}$ of CAT stock solutions. The total reaction mixture was made to $1.425 \mathrm{ml}$ with the same Tris- $\mathrm{HCl}$ buffer. Autooxidation of pyrogallol was monitored by measuring absorbance at $420 \mathrm{~nm}$ at 1-minute intervals for 5 minutes. SOD activity was determined from a standard curve of percentage of inhibition of pyrogallol auto-oxidation with a known SOD activity. One unit of SOD is defined as the amount that shows $50 \%$ inhibition at room temperature and a $\mathrm{pH}$ of 7.8 .

\section{Estimation of catalase (CAT) activity}

$5 \mathrm{ml}$ solution of $0.01 \mathrm{M}$ hydrogen peroxide was prepared with the buffer solution and used as a substrate for the assay. $20 \mu \mathrm{l}$ of the supernatant sample was mixed with $780 \mu \mathrm{l}$ of buffer/hydrogen peroxide and $200 \mu \mathrm{l}$ of distilled water. The enzyme activity was measured at $240 \mathrm{~nm}$ by spectrophotometry for $60 \mathrm{~s}$ by reading the change in absorbance between the fifteenth and sixtieth second. The results are expressed in $\mu \mathrm{mol} \mathrm{H}_{2} \mathrm{O}_{2} / \mathrm{min} / \mathrm{mg}$ of protein [28].

\section{Estimation of GST activity}

GST was assayed with the method used by Habig [29] by adding 1-chloro-2,4-dinitrobenzene (CDNB). Change in optic density was read at $340 \mathrm{~nm}$ for $3 \mathrm{~min}$ at an interval of $30 \mathrm{~s}$. The GST activity was expressed as nmol of CDNB conjugate formed $/ \mathrm{min} / \mathrm{mg}$ protein.

\section{Estimation of GPx activity}

GPx activity was measured using a modified version of that used by Hafeman [30]. The reaction mixture contained GSH, phosphate buffer, $\mathrm{H}_{2} \mathrm{O}_{2}$, TCA (trichloroacetic acid), $\mathrm{Na}_{2} \mathrm{HPO}_{4}$ and DTNB (5, $5^{\prime}$-dithiobis (2-nitrobenzoic acid)). The rate of reaction was measured by the decrease in GSH, which was determined by measuring the reaction products of DTNB and GSH (absorbance of the ions at $412 \mathrm{~nm}$ ). One unit of enzyme activity was defined as a decrease of $1 \mu \mathrm{mol} / \mathrm{L}$ of $\mathrm{GSH}$ concentration at $37^{\circ} \mathrm{C}$ and $\mathrm{pH} 6.5$, while non-enzymatic reactions were excluded.

\section{Estimation of lipid peroxide}

Lipid peroxide content in gastric mucosal tissues was determined by thiobarbituric acid reaction as described by Ohkawa [31]. The lipid peroxide concentration was expressed as nmol MDA/mg protein. 


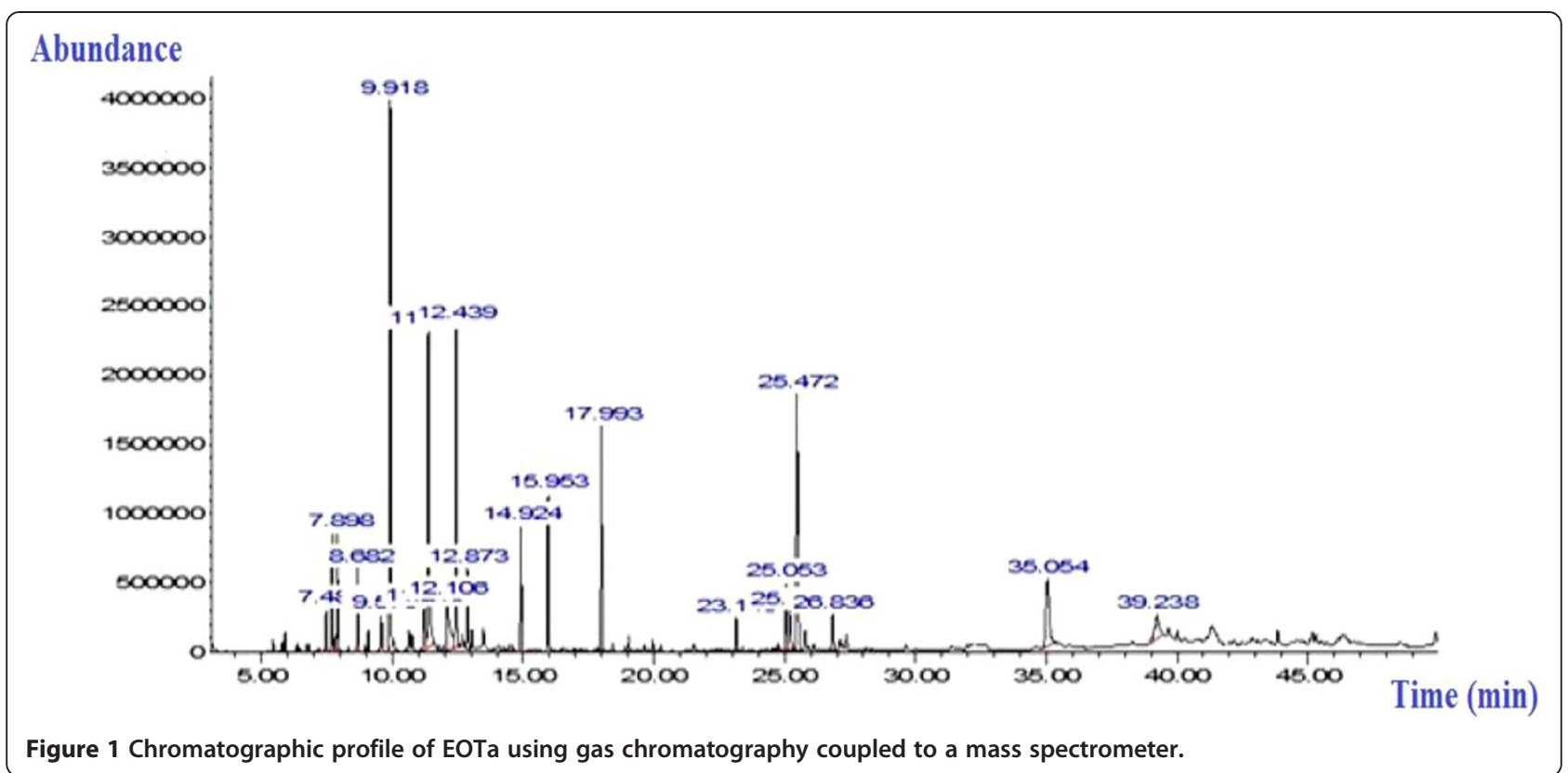

\section{Measurement of mucus production}

The gastric mucosa of each rodent was gently scraped using a glass slide and the mucus obtained was weighed using a precision electronic balance [32].

\section{Acute toxicity study in rodents}

Adult male and female Wistar Dawley rats (6-8 weeks old; $150-180 \mathrm{~g})$ were obtained from the Experimental Animal House, Pasteur Institute, University of Tunisia. The rodents were given standard pellets as food and clean tap water. Thirty six rats were assigned to six groups of six rats each. The female rats were divided into control, low dose and high dose groups and the same approach was taken for the males. The rodents fasted overnight, then were given doses of EOTa at 300 and $500 \mathrm{mg} / \mathrm{kg}$ body weight, and continued fasting for 3-4 h after dosing every day for 14 days. Behavioral changes, weight, consumption of food and water, clinical signs of toxicity, and mortality were recorded daily [33].

\section{Statistical analysis}

The values were reported as mean \pm S.E.M. The significance $(\mathrm{p}<0.05)$ of the results was assessed by one-way analysis of variance (ANOVA), followed by Bonferroni's

Table 2 Chemical composition of essential oils extracted from Thymus algeriensis using analysis by GC-MS

\begin{tabular}{|c|c|c|c|c|c|}
\hline NO. & $\mathrm{RT}^{\mathrm{a}}$ & $\mathrm{RI}^{\mathrm{b}}$ & Components $^{c}$ & Peak area (\%) EOTa ${ }^{d}$ & Identification methods ${ }^{\mathrm{e}}$ \\
\hline 1 & 7.481 & 1017 & a -terpinene & 1.18 & GC-MS-RI ${ }^{f}$ \\
\hline 2 & 7.705 & 1025 & $\rho$-cymene & 3.22 & GC-MS \\
\hline 3 & 7.899 & 1031 & 1,8-cineole & 3.45 & GC-MS \\
\hline 4 & 8.683 & 1060 & $\gamma$-terpinene & 2.43 & GC-MS-CAS $\#$ \\
\hline 5 & 9.576 & 1089 & Terpinolene & 1.35 & GC-MS-CAS\# \\
\hline 6 & 9.919 & 1098 & Linalool & 18.05 & GC-MS \\
\hline 7 & 11.378 & 1146 & Camphor & 13.03 & GC-MS \\
\hline 8 & 12.431 & 1176 & 4-carvomenthenol & 11.2 & GC-MS \\
\hline 9 & 15.956 & 1289 & Bornyl acetate & 5.41 & GC-MS \\
\hline 10 & 23.142 & 1511 & $\gamma$-cadinene & 1.21 & GC-MS \\
\hline 11 & 25.054 & 1578 & Spathulenol & 2.80 & GC-MS \\
\hline 12 & 25.197 & 1582 & Caryophyllene oxide & 2.09 & GC-MS \\
\hline 13 & 25.471 & 1590 & Viridiflorol & 11.71 & GC-MS \\
\hline
\end{tabular}

${ }^{\mathrm{a}} \mathrm{RT}$ (retention time), ${ }^{\mathrm{b}} \mathrm{RI}$ (retention index) measured relative to $n$-alkanes $\left(\mathrm{C}_{10}-\mathrm{C}_{15}\right) ;{ }^{\mathrm{c}}$ Components listed in order of their retention index on HP-5 column, ${ }^{\mathrm{d}} \mathrm{Plant}$ codes; ${ }^{\mathrm{e}} \mathrm{GC}-\mathrm{MS}$ : identification based on a high match of mass spectra retention; ${ }^{\mathrm{f}} \mathrm{RI}$ Identified by retention index and compared with those reported in the literature [37]; ${ }^{9} \mathrm{CAS}$ \# = Chemical Abstracts service reference number compared with those reported in the literature [38]. 


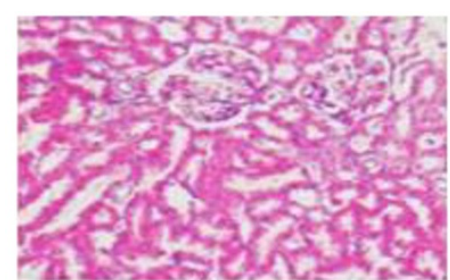

(a)

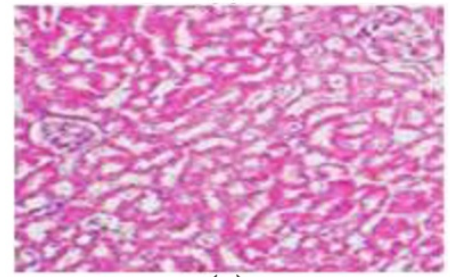

(c)

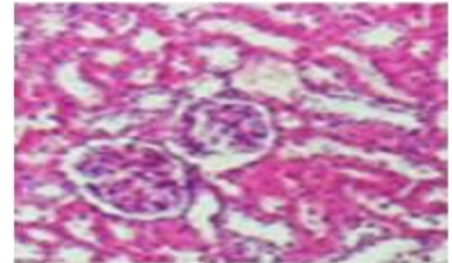

(e)

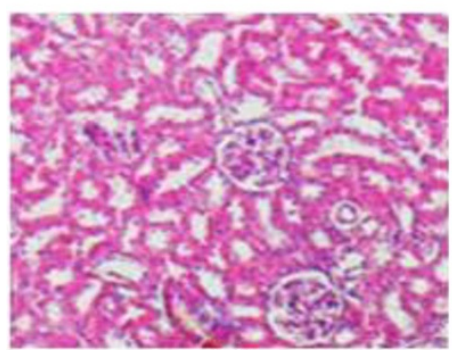

(g)

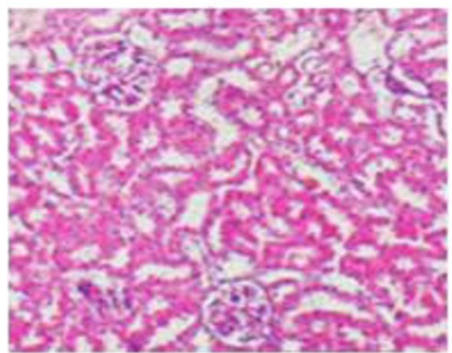

(i)

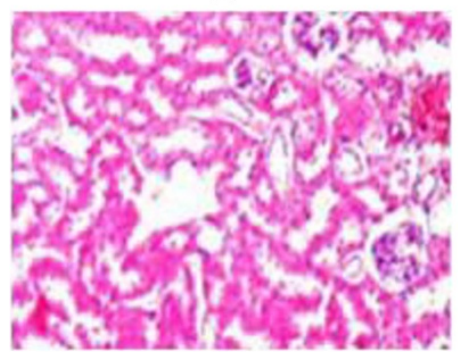

(k)

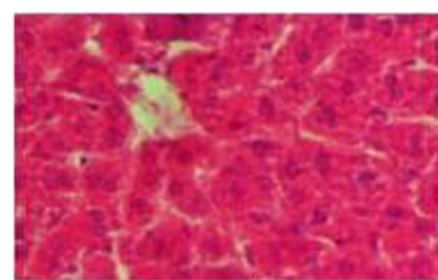

(b)

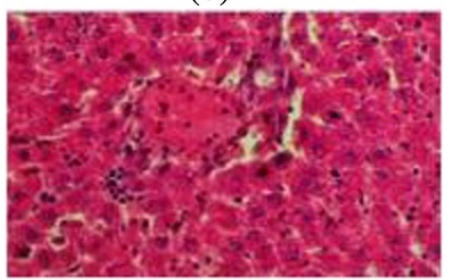

(d)

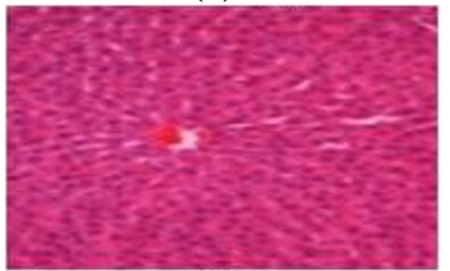

(f)

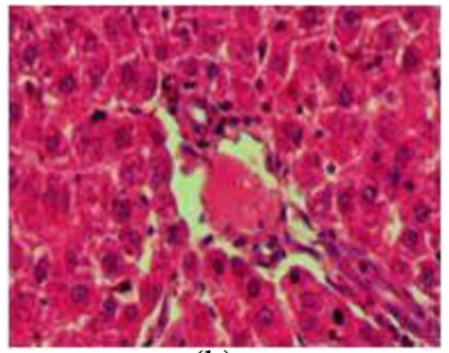

(h)

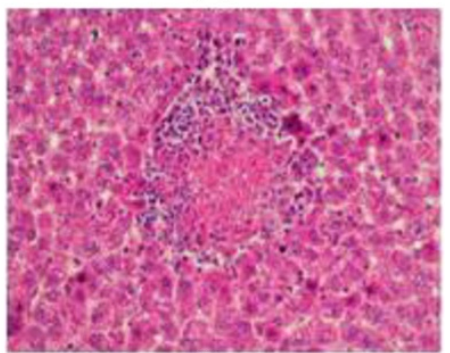

(j)

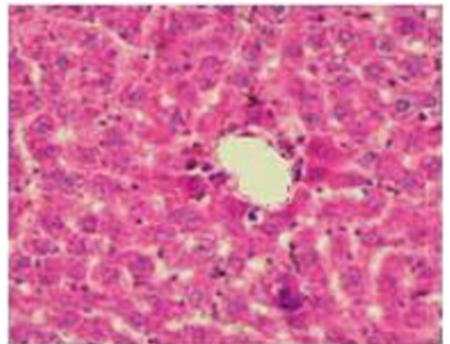

(1)

Figure $\mathbf{2}$ (See legend on next page.) 
(See figure on previous page.)

Figure 2 Histological sections of liver and kidney from the acute toxicity test. Female rats (1a and 1 b): Control group; female rats (1 c and 1d): treated with $300 \mathrm{mg} / \mathrm{kg}$ of EOTa; female rats (1e and $1 \mathbf{f}$ ) treated with $500 \mathrm{mg} / \mathrm{kg}$ of EOTa; male rats (1/g and $1 \mathbf{h}$ ): control group; male rats (1) and $1 \mathbf{j}$ ): treated with $300 \mathrm{mg} / \mathrm{kg}$ of EOTa; male rats $(1 \mathbf{k}$ and $1 \mathbf{l})$ treated with $500 \mathrm{mg} / \mathrm{kg}$ of EOTa. There is no significant differences in the structure of liver and kidney between treated and control groups (Hematoxylin \& Eosin stain $20 \times$ magnifications).

test for multiple comparison or Dunnett's multiple range test.

\section{Results and discussion}

In this investigation, $\mathrm{GC} / \mathrm{MS}$ analysis made it possible to identify 13 compounds in EOTa, which accounting for $77.75 \%$ of the total oil content. The chromatogram in Figure 1 shows four main components in EOTa (Table 2): Linalool (18.05\%), Camphor (13.03\%), 4-carvomenthenol (11.2\%) and Viridiflorol (11.71\%). Extraction procedures for EOTa resulted in a yield of $2.36 \%$. Previous chemical reports of the essential oil obtained from 14 Tunisian natural populations of Thymus algeriensis leaves collected from different geographical regions revealed that the major components were 1,8-cineole (17.7\%), $\alpha$-pinene (15.5\%), and camphor (8.2\%) [34]. Zouari et al. [35] found that the major compounds of $8 \mathrm{~T}$. algeriensis populations analyzed were $\alpha$-pinene (7.41-13.94\%), 1,8-cineole (7.55$22.07 \%)$, cis-sabinene hydrate (0.10-12.95\%), camphor (1.55-11.86\%), terpenyl acetate (0-14.92\%) and viridiflorol (0-11.49\%). In terms of its phytochemical constituents, Thymus algeriensis generally contains major classes of secondary metabolites such as flavonoids, phenolic compounds and triterpenoids, to name but a few. The presence of secondary products in fairly high concentrations has commonly been used to explain the claimed curative and palliative efficacy of a variety of traditional herbal medicines and the reports of profound beneficial effects of certain foodstuffs on health [36]. This finding contributed to the antiulcer pharmacological validation of this species, lending more credence to clinical applications for the traditional treatment of stomach complaints symptomatic of peptic ulcer disease.

The equilibrium between the therapeutic versus toxicological effects of a drug is a vital parameter in assessing its applicability in relation to pharmacological action [39]. As a part of this pharmacological study, EOTa was investigated for its acute and general toxicity in rodents. In the acute toxicity study, EOTa at doses of 300 and $500 \mathrm{mg} \mathrm{kg}^{-1}$ exhibited no signs of toxicity. Anatomical results showed an absence of abnormal organic damage to the rats' organs.

Neither female nor male rats experienced any toxicity or mortality and there were no abnormal physiological or behavioral changes, nor alterations in body weight at any time during the 14 days of observation (Figure 2 and Figure 3). Histological examination of the liver and kidney did not show any difference compared to the control group.

EOTa treatment (54-180 mg/kg, p.o.) caused a dosedependent reduction in $\mathrm{HCl} /$ ethanol-induced gastric lesions, decreasing the ulcer index and percentage of inhibition mainly at doses of $180 \mathrm{mg} / \mathrm{kg}$ for male rats (88\%) and between 117 and $180 \mathrm{mg} / \mathrm{kg}$ for female rats (96.25 and 98.85\%) (Table 3). In this study, omeprazole can protect the gastric mucosa against $\mathrm{HCl} /$ ethanol-induced ulceration (65.95\%).

The results of antiulcerogenic activity of EOTa on gastric ulcers induced by the $\mathrm{HCl} /$ ethanol solution are shown in Figure 4. The acidity of the gastric content in experimental animals pretreated with EOTa (female rats) was decreased significantly compared to that of the ulcer control group $(p<0.05)$. The mucus production of gastric mucosa (Table 3$)$ also increased significantly $(p<0.05)$ in male rats treated with $180 \mathrm{mg} / \mathrm{kg}$ and female rats (117 and $180 \mathrm{mg} / \mathrm{kg}$ ) compared to the ulcer control group.

Oral administration of the damaging agent to the control group clearly produced mucosal damage characterized by multiple hemorrhage red bands of different sizes along the long axis of the glandular stomach as described in other studies [40,41].

Excessive acidified ethanol ingestion is an etiological factor that gives rise to gastritis characterized by mucosal edema, sub-epithelial hemorrhage, cellular exfoliation and inflammatory cell infiltration [42].

Pretreatment with EOTa $(117 \mathrm{ml} / \mathrm{kg}$ and $180 \mathrm{ml} / \mathrm{kg})$ significantly reversed these changes for female rats (Figures 4 and 5). Stomachs of male and female rats treated with a higher dose of EOTa showed only mild congestion; otherwise, stomach appearance was normal. There was a clear change in the gross appearance of the gastric mucosa compared to the acidified treated group. Hence, it is likely that the anti-ulceration mechanism of EOTa is due to its antioxidant effect.

In addition, administratering EOTa to female rats was shown to decrease the acidified ethanol-induced gastric ulceration. The mechanism of this protective effect includes the modulatory role of female hormones on vascular permeability and an increase in mucus secretion [43]. In another report, both progesterone and estrogens attenuated the area of acute gastric lesions induced by aspirin and indomethacin [44]. In contrast, testosterone-induced delays in ulcer healing involves the fall in gastric microcirculation at the margin of lingual and gastric ulcers and the excessive production and release of proinflammatory 

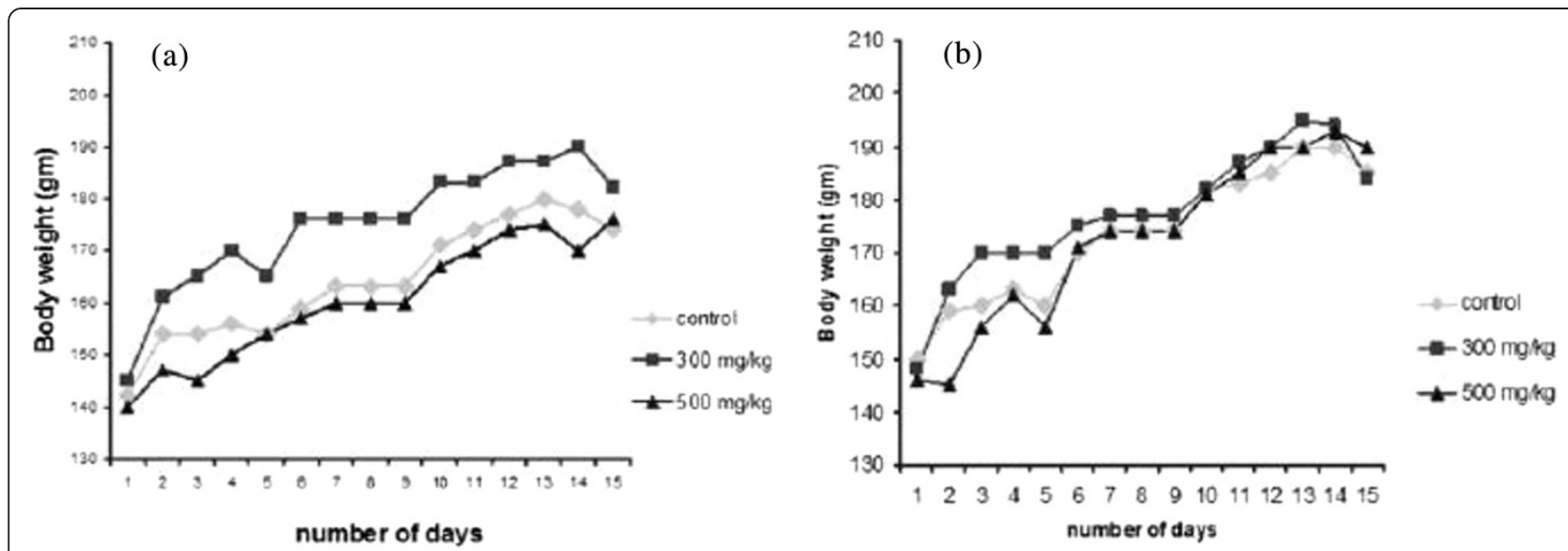

Figure 3 Body weight gain in rats treated orally with vehicle, Thyme (EOTa, $300 \mathrm{mg} / \mathrm{kg}$ ), and Thyme (EOTa, $500 \mathrm{mg} / \mathrm{kg}$ ) for $15 \mathrm{days}$. Results are mean $\pm S E M, n=6$. ANOVA, $P>0.05$ between groups in the same day. (a) for male rats and (b) for female rats.

cytokine IL-1b. Treatment with progesterone significantly accelerated ulcer healing and increased the gastric and lingual blood flow at the margin of these ulcers [43].

Our results revealed the protection of the gastric mucosa and inhibition of leukocyte infiltration into the gastric wall in rats pretreated with EOTa. Activation and infiltration of neutrophils appear to be involved in the initial process that forms the lesions [45]. Neutrophil accumulation in gastric mucosa has been shown to induce microcirculatory abnormalities [46]. The present study established that pretreatment with EOTa reduced neutrophil infiltration into ulcerated tissue.

The formation of gastric mucosal lesions by necrotizing agents such as $\mathrm{HCl}$ and $\mathrm{EtOH}$ has been reported to involve the depletion of gastric defensive mechanisms [47].

Of all these changes, the most prominent are increased capillary permeability and production of free radicals [48], which attack and damage cell membranes, attract neutrophils and initiate an inflammatory response [49].
This was further substantiated by histological findings where a marked reduction in gastric mucosal damage and cellular influx was observed. Some consistent treatmentrelated histopathological abnormalities were found in rats of either sex. These results indicated that EOTa exhibited a protective effect against $\mathrm{HCl} /$ Ethanol-induced ulcerogenesis in rats. Omeprazole, on the other hand, was effective in alleviating oxidative stress in the $\mathrm{HCl} /$ Ethanol model. Omeprazole is the first of a new class of drugs that inhibit gastric secretion by altering the activity of $\mathrm{H}^{+} / \mathrm{K}^{+}$-ATPase [50,51]; it is not charged and can cross cell membranes [52]. Due to being a weak base, omeprazole accumulates in the acidic space of the parietal cell and, by acid-catalyzed rearrangement, becomes a thiol-reactive cationic sulfenic acid and/or sulfenamide that binds to cysteinyl-SH groups to form disulfides [10].

The levels of lipid peroxidation products, GSH and activities of enzymic antioxidants in gastric mucosa of experimental animals are tabulated in Table $4 . \mathrm{HCl} /$ ethanol in

Table 3 Measurement of the total no. of ulcers, ulcer index, inhibition percentage, mucus and pH

\begin{tabular}{|c|c|c|c|c|c|c|}
\hline Groups number & Treatment (p.o) & $\mathrm{PH}$ & $\begin{array}{l}\text { Mucus production } \\
\text { ( } \mu \mathrm{g} / \mathrm{g} \text { wet tissue) }\end{array}$ & $\begin{array}{l}\text { Total no. of ulcers } \\
(\text { mean } \pm \text { SD) }(n=6)\end{array}$ & $\begin{array}{l}\text { Ulcer index } \\
(\text { mean } \pm \text { SD) }(n=6)\end{array}$ & $\%$ ulcer inhibition \\
\hline Group 1 & Control $\left(F^{a}\right)$ & $2.7 \pm 0.65^{*}$ & $0.85 \pm 0.52^{*}$ & $14 \pm 2.20^{*}$ & $17 \pm 1.80^{*}$ & $0.00^{*}$ \\
\hline Group 2 & control $\left(M^{b}\right)$ & $2.95 \pm 0.21^{*}$ & $0.43 \pm 0.14^{*}$ & $16.5 \pm 4.20^{*}$ & $23.5 \pm 7.30^{*}$ & $0.00^{*}$ \\
\hline Group 3 & Omeprazole & $4.37 \pm 0.32^{\#}$ & $1.2 \pm 0.20^{\#}$ & $5 \pm 2.10^{\#}$ & $8 \pm 6.13^{\#}$ & $65.95^{\#}$ \\
\hline Group 4 & EOTa (MR) & $3.1 \pm 0.80^{* \#}$ & $0.42 \pm 0.40^{* \#}$ & $13 \pm 0.70^{* \#}$ & $14.83 \pm 1.70^{* \#}$ & $36.90^{* \#}$ \\
\hline Group 5 & EOTa (MR) & $3.42 \pm 0.87^{* \#}$ & $0.8 \pm 0.20^{* \#}$ & $10 \pm 1.80^{* \#}$ & $11.42 \pm 3.80^{* \#}$ & $51.40^{* \#}$ \\
\hline Group 6 & EOTa (MR) & $5.79 \pm 0.22^{* \#}$ & $2.2 \pm 0.80^{* \#}$ & $1.5 \pm 0.32^{* \#}$ & $2.82 \pm 2.21^{* \#}$ & $88.00^{* \#}$ \\
\hline Group 7 & EOTa (FR) & $5.13 \pm 0.26^{* \#}$ & $2.55 \pm 0.32^{* \#}$ & $3.5 \pm 2.70^{* \#}$ & $5.3 \pm 1.67^{* \#}$ & $77.44^{* \#}$ \\
\hline Group 8 & EOTa (FR) & $5.88 \pm 0.20^{* \#}$ & $2.85 \pm 0.46^{* \#}$ & $0.84 \pm 1.33^{* \#}$ & $0.88 \pm 0.22^{* \#}$ & $96.25^{* \#}$ \\
\hline Group 9 & EOTa (FR) & $6.14 \pm 0.38^{* \#}$ & $3.18 \pm 0.72^{* \#}$ & $0.25 \pm 0.05^{* \#}$ & $0.27 \pm 0.93^{* \#}$ & $98.85^{* \#}$ \\
\hline
\end{tabular}

${ }^{\mathrm{a}}$ FR: Female Rats; ${ }^{\mathrm{b}} \mathrm{MR}$ : Male Rats; All values are expressed as mean 6 standard error mean. Mean difference is significant at the $\mathrm{p}<0.05$ level (ANOVA followed by Dunnett's test). ${ }^{*}$ significant when compared to the ulcer control groups (a and b). " significant when compared to the reference control group (c). 


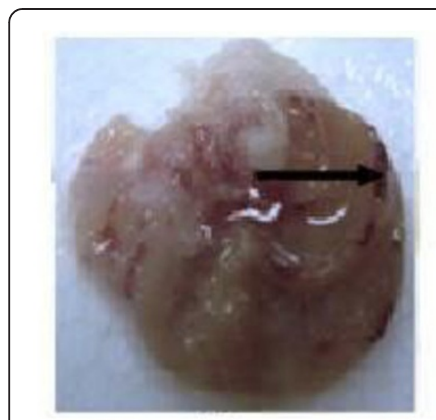

(a)

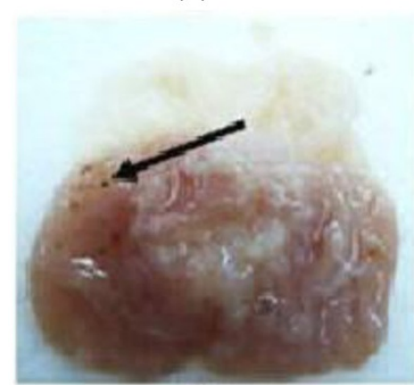

(e)

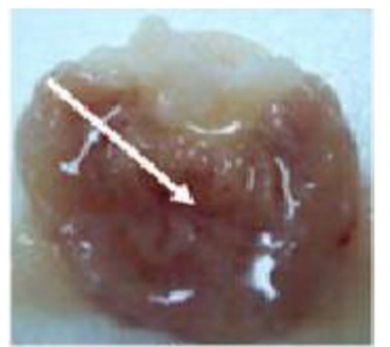

(i)

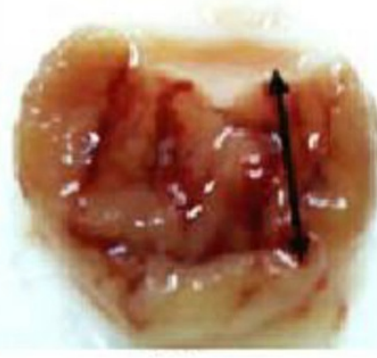

(b)

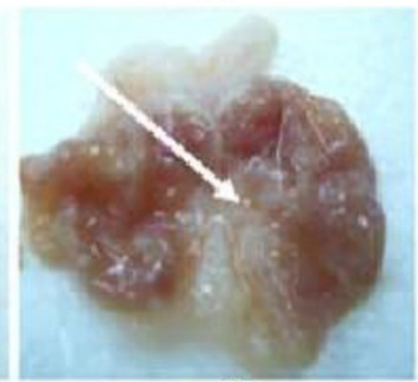

(f)

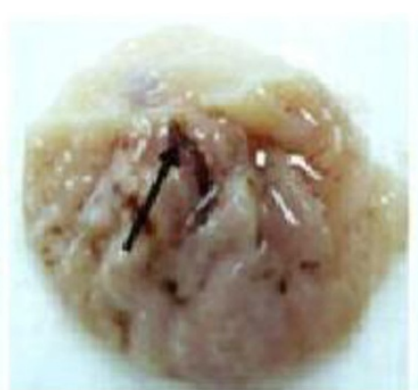

(c)

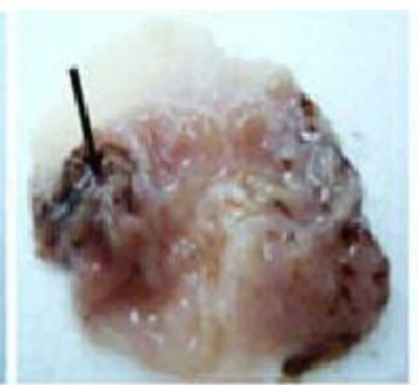

(g)

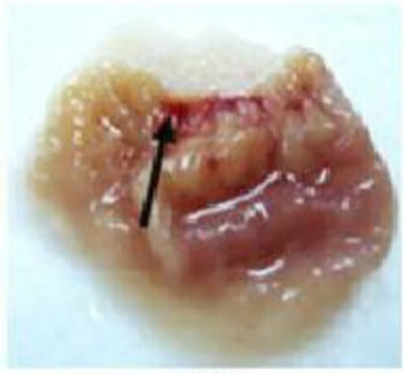

(d)

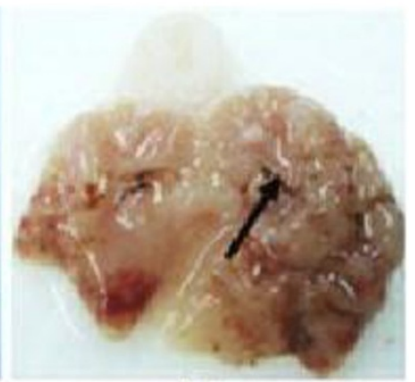

(h)

Figure 4 Gross appearance of the gastric mucosa in rats. (a) stamach of control (FR). Severe injuries are seen in the gastric mucosa (hemorrhagic necrosis of gastric mucosa). (b) stomach of control (MR). Severe injuries are seen in the gastric mucosa (hemorrhagic necrosis of gastric mucosa). (c) stomach of rats pre-treated with omeprazole (20 mg/kg). Moderate injuries are seen in the gastric mucosa. (d) stomach of female rat pre-treated with EOTa (54 mg/kg). Mild injuries can be seen in the gastric mucosa. (e) stomach of female rat pre-treated with EOTa (117 mg/kg). Very mild injuries can be seen in the gastric mucosa. (f) stomach of female rat pre-treated with EOTa (800 mg/kg). No injuries can be seen in the gastric mucosa instead flattening of gastric is visible (white arrow). (g) stomach of male rat pre-treated with EOTa (54 mg/kg). Severe injuries can be seen in the gastric mucosa. (h) stomach of male rat pre-treated with EOTa $(117 \mathrm{mg} / \mathrm{kg}$ ). Severe injuries can be seen in the gastric mucosa. (i) stomach of male rat pre-treated with EOTa (180 mg/kg). Very mild injuries can be seen in the gastric mucosa instead flattening of gastric mucosa is visible (white arrow).

female rats $(180 \mathrm{mg} / \mathrm{kg})$ significantly increased ulceration with a concomitant decrease in LPO levels $(0.019 \pm$ $0.09 \mathrm{mmol} / \mathrm{mg}$ vs $0.190 \pm 0.02$ and $0.224 \pm 0.02 \mathrm{mmol} / \mathrm{mg}$, $\mathrm{P}<0.001)$ while SOD $(178.66 \pm 0.01 \mathrm{U} / \mathrm{mg}$ protein vs $17 \pm$ 0.045 and $15.38 \pm 0.06 \mathrm{U} / \mathrm{mg}$ protein, $\mathrm{P}<0.001), \mathrm{GSH}$ $(3.798 \pm 0.23 \mu \mathrm{mol} / \mathrm{mg}$ protein vs $0.085 \pm 0.840 .050 \pm$ $0.00 \mu \mathrm{mol} / \mathrm{mg}$ protein, $\mathrm{P}<0.001)$, GPx $(6.1 \pm 0.75 \mu \mathrm{mol}$ $\mathrm{GSH} / \mathrm{mg}$ protein $/ \mathrm{ml}$ vs $1.82 \pm 0.54$ and $1.25 \pm 0.09 \mu \mathrm{mol}$ $\mathrm{GSH} / \mathrm{mg}$ protein $/ \mathrm{ml}, \mathrm{P}<0.001)$, GST $(9.07 \pm 0.72 \mathrm{nmol} /$ $\mathrm{min} / \mathrm{mg}$ protein vs $0.9 \pm 0.67$ and $0.82 \pm 0.02 \mathrm{nmol} / \mathrm{min} / \mathrm{mg}$ protein, $\mathrm{P}<0.001)$ and CAT $\left(20.24 \pm 0.08 \mu \mathrm{mol} \mathrm{H}_{2} \mathrm{O}_{2}\right.$ consumed $/ \mathrm{min} / \mathrm{mg}$ protein vs $2.13 \pm 0.33$ and $2.49 \pm 0.87 \mu \mathrm{mol}$ $\mathrm{H}_{2} \mathrm{O}_{2}$ consumed/min/mg protein, $\mathrm{P}<0.001$ ) levels were markedly increased compared to the disease control in gastric mucosal homogenate. In this study SOD, CAT, GPx,
GST \& GSH activities were significantly elevated by the administration of EOTa to treat rats, suggesting that it has the ability to restore these enzymes.

The increase in LPO may suggest a possible mechanism of tissue injury by reactive oxygen intermediates [53]. Hydroxyl radicals thus generated oxidize important cellular constituents such as structural and functional proteins, and membrane lipids as well as deplete glutathione. Lipid peroxidation causes loss of membrane fluidity, impaired ion transport and membrane integrity and finally loss of cellular functions [54].

Further, it was observed that in $\mathrm{HCl} /$ ethanol- administered rats there was increased generation of reactive oxygen species estimated by increased level of TBARS and attenuated levels of GSH, as well as SOD, CAT and GPx 


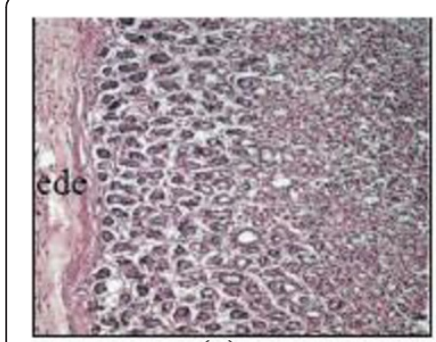

(a)

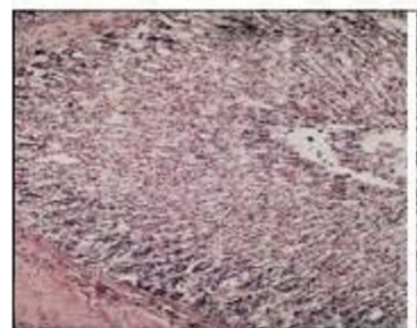

(e)

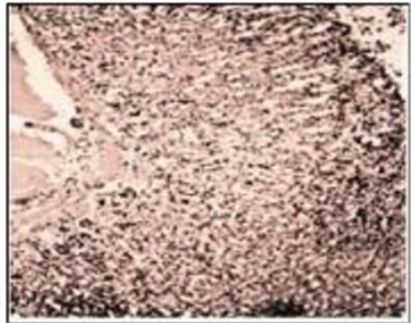

(i)

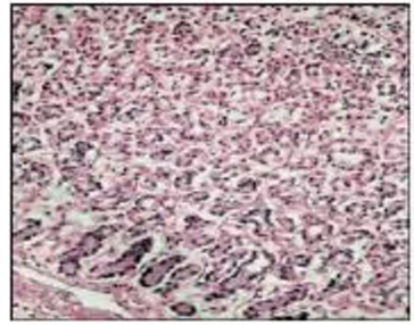

(m)

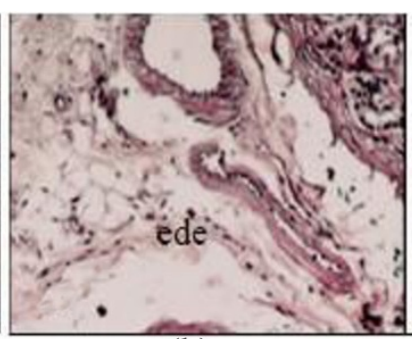

(b)

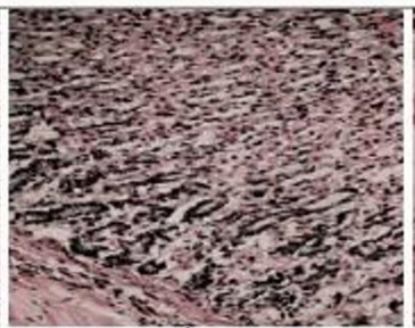

(f)

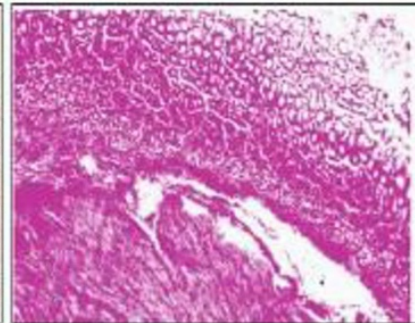

(j)

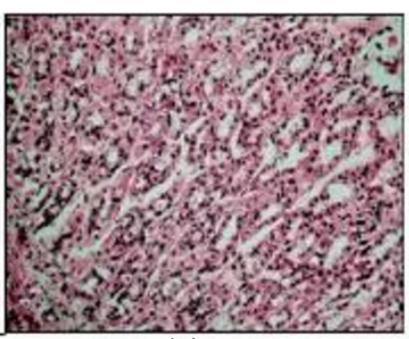

(c)

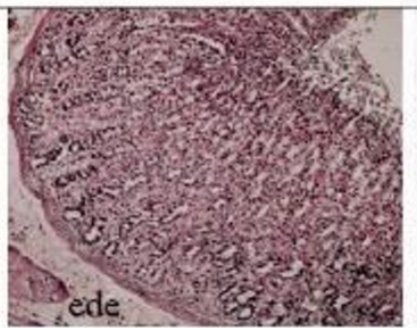

(g)

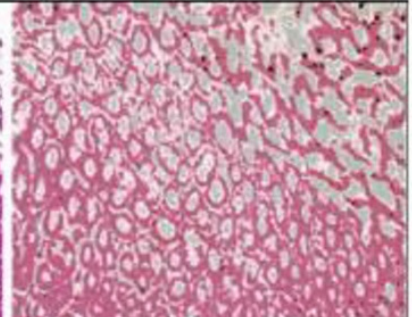

(k)

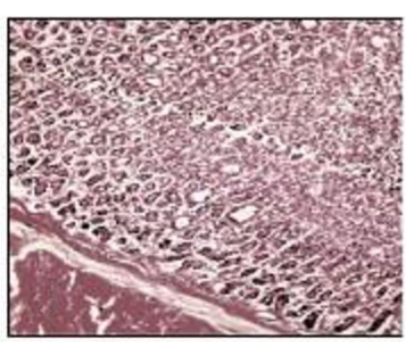

(d)

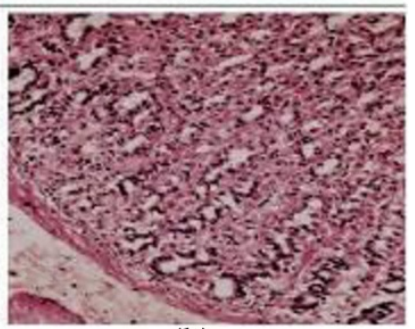

(h)

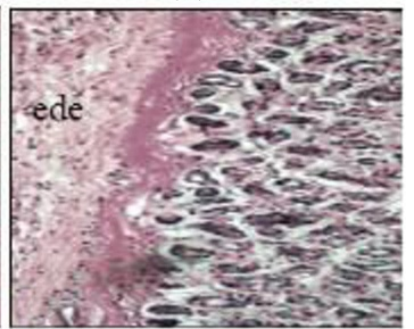

(1)

Figure 5 Photomicrographs of gastric mucosa (Hematoxylin-Eosin staining: magnification 20x for a, b, d, e, g, i, j and l; 40x for c, f, h, $\mathbf{k}$ and $\mathbf{m}$ ). (a) micrograph of female rats pretreated with $\mathrm{HCl} /$ ethanol (ulcer control group), there is epithelial exfoliation and extensive edema (ede) of submucosa layer with distorted glands; $(\mathbf{b}, \mathbf{c})$ micrograph of male rats pretreated with $\mathrm{HCl} /$ ethanol (ulcer control group) shows discontinuity in the lining epithelium with exudates in the lumen submucosal edema (ede) of submucosa layer with distorted glands. (d) Omeprazole groups showing epithelium and submucosa with normal characteristics. The EOTa, at 54 mg kg -1 (e, f), 117 mg kg-1 (g,h) and $180 \mathrm{mg} \mathrm{kg}_{-1}$ (i) (for FR) showign mocosal regeneration with exudates in lumen with some inflammatory cells, mild mucosal damage, mild leukocyte infiltration, and mild submucosal edema. The EOTa, at $54 \mathrm{mg} \mathrm{kg}_{-1}$ (j, $\mathbf{k}$ ) and $117 \mathrm{mg} \mathrm{kg} \mathrm{g}_{-1}$ (I) (for MR) showign clearly mucosal hemorrage, submucosal edema, leukocyte and neutrophil infiltration, inflammatory cell and abundant neutrophils, but The EOTa, at 180 mg kg ${ }_{-1}$ (m) showing clearly moderate mucosal damage and moderate submucosal edema.

activities and GST along with decreased secretion of mucus (Figure 6) which was reversed in EOTa 180 treatment groups. A significant decrease in gastric GSH following $\mathrm{HCl} /$ ethanol administration indicated massive generation of free radicals. Our results corresponded with earlier reports showing a depletion of sulfhydryls in ethanol-induced gastric lesions [55]. Treatment with EOTa produced a significant increase in the level of GSH and activities of SOD, CAT, GPx and GST, and a significant decrease in the level of TBARS in the $\mathrm{HCl}$ / ethanol model (Table 4). Reduced glutathione is one of the most abundant non-enzymatic antioxidant biomolecules present in the tissues [56]. Its functions are removing free oxygen species such as $\mathrm{H}_{2} \mathrm{O}_{2}$, superoxide anions and alkoxy radicals, maintaining membrane protein thiols and acting as a substrate for GPx and glutathione $S$ - transferase (GST) [57]. The non-availability of GSH decreases the activities of GSH- dependent 
Table 4 Measurement of the total protein concentration, antioxidant activity, lipid peroxidation of the tissue homogenates

\begin{tabular}{|c|c|c|c|c|c|c|c|}
\hline Groups & $\begin{array}{l}\text { Lipid peroxidation } \\
\text { nmol MDA/mg } \\
\text { protein }\end{array}$ & $\begin{array}{l}\text { Protein } \\
\text { concentration } \\
(\mu \mathrm{g} / \mathrm{ml})\end{array}$ & $\begin{array}{l}\text { GSH } \\
(\mu \mathrm{mol} / \mathrm{mg} \\
\text { protein })\end{array}$ & $\begin{array}{l}\text { SOD } \\
\text { U/mg } \\
\text { protein }\end{array}$ & $\begin{array}{l}\text { CAT } \mu \mathrm{mol} \mathrm{H}_{2} \mathrm{O}_{2} \\
\text { consumed } / \mathrm{min} / \mathrm{mg} \\
\text { protein }\end{array}$ & $\begin{array}{l}\text { GPx } \mu \mathrm{mol} \\
\mathrm{GSH} / \mathrm{mg} \\
\text { protein/ml }\end{array}$ & $\begin{array}{l}\text { GST nmol of CDNB } \\
\text { conjugate formed } / \mathrm{min} / \mathrm{mg} \\
\text { protein }\end{array}$ \\
\hline $\begin{array}{l}\text { Group } \\
1\end{array}$ & $0.190^{*} \pm 0.02$ & $23.75^{*} \pm 0.75$ & $\begin{array}{l}0.085^{*} \pm \\
0.84\end{array}$ & $\begin{array}{l}17^{*} \pm \\
0.45\end{array}$ & $2.13^{*} \pm 0.33$ & $1.82^{*} \pm 0.54$ & $0.9^{*} \pm 0.67$ \\
\hline $\begin{array}{l}\text { Group } \\
2\end{array}$ & $0.224^{*} \pm 0.02$ & $16.25^{*} \pm 0.08$ & $\begin{array}{l}0.050^{*} \pm \\
0.00\end{array}$ & $\begin{array}{l}15.38^{*} \pm \\
0.06\end{array}$ & $2.49^{*} \pm 0.87$ & $1.25^{*} \pm 0.09$ & $0.82^{*} \pm 0.02$ \\
\hline $\begin{array}{l}\text { Group } \\
3\end{array}$ & $0.098^{\#} \pm 0.03$ & $113.75^{\#} \pm 0.54$ & $\begin{array}{l}1.282^{\#} \pm \\
0.51\end{array}$ & $\begin{array}{l}94.54^{\#} \\
\pm 0.02\end{array}$ & $11.15^{\#} \pm 0.72$ & $4.82^{\#} \pm 0.68$ & $6.44^{\#} \pm 0.05$ \\
\hline $\begin{array}{l}\text { Group } \\
4\end{array}$ & $0.134^{* \#} \pm 0.03$ & $47.5^{* \#} \pm 0.76$ & $\begin{array}{l}0.55^{* \#} \pm \\
0.71\end{array}$ & $\begin{array}{l}23.25^{* \#} \\
\pm 0.04\end{array}$ & $8.94^{* \#} \pm 0.02$ & $1.81^{* \#} \pm 0.19$ & $0.84^{* \#} \pm 0.04$ \\
\hline $\begin{array}{l}\text { Group } \\
5\end{array}$ & $0.093^{* \#} \pm 0.02$ & $90^{* \#} \pm 0.05$ & $\begin{array}{l}1.260^{* \#} \pm \\
0.76\end{array}$ & $\begin{array}{l}27.85^{* \#} \\
\pm 0.06\end{array}$ & $4.25^{* \#} \pm 0.80$ & $2.22^{* \#} \pm 0.66$ & $1.02^{* \#} \pm 0.08$ \\
\hline $\begin{array}{l}\text { Group } \\
6\end{array}$ & $0.024^{* \#} \pm 0.03$ & $191^{* \#} \pm 0.21$ & $\begin{array}{l}3.895^{* \#} \pm \\
0.79\end{array}$ & $\begin{array}{l}91.85^{* \#} \\
\pm 0.03\end{array}$ & $19.68^{* \#} \pm 0.40$ & $4^{* \#} \pm 0.05$ & $4.96^{* \#} \pm 0.37$ \\
\hline $\begin{array}{l}\text { Group } \\
7\end{array}$ & $0.036^{* \#} \pm 0.08$ & $122.5^{* \#} \pm 0.42$ & $\begin{array}{l}1.926^{* \#} \pm \\
0.60\end{array}$ & $\begin{array}{l}121.73^{* \#} \\
\pm 0.01\end{array}$ & $11.46^{* \#} \pm 0.90$ & $3.8^{* \#} \pm 0.78$ & $6.93^{* \#} \pm 0.57$ \\
\hline $\begin{array}{l}\text { Group } \\
8\end{array}$ & $0.021^{* \#} \pm 0.01$ & $178.75^{* \#} \pm 0.18$ & $\begin{array}{l}2.880^{* \#} \pm \\
0.12\end{array}$ & $\begin{array}{l}153.33^{* \#} \\
\pm 0.07\end{array}$ & $18.31^{* \#} \pm 0.10$ & $5.82^{* \#} \pm 0.98$ & $7.24^{* \#} \pm 0.73$ \\
\hline $\begin{array}{l}\text { Group } \\
9\end{array}$ & $0.019^{* \#} \pm 0.09$ & $193^{* \#} \pm 0.02$ & $\begin{array}{l}3.798^{* \#} \pm \\
0.23\end{array}$ & $\begin{array}{l}178.66^{* \#} \\
\pm 0.01\end{array}$ & $20.24^{* \#} \pm 0.08$ & $6.1^{* \#} \pm 0.75$ & $9.07^{* \#} \pm 0.72$ \\
\hline
\end{tabular}

This experiment consists of the control (FR) (Group 1), the control (MR) (Group 2), the reference group pretreated with $20 \mathrm{mg} \mathrm{kg}^{-1}$ of omeprazole (Group 3), the experimental groups MR (Groups 4-6): received $54 \mathrm{mg} / \mathrm{kg}, 117 \mathrm{mg} / \mathrm{kg}$ and $180 \mathrm{mg} / \mathrm{kg}$ of the EOT as a pre-treatment and the experimental groups FR (Groups 7-9): received $54 \mathrm{mg} / \mathrm{kg}$, $117 \mathrm{mg} / \mathrm{kg}$ and $180 \mathrm{mg} / \mathrm{kg}$ of the EOT as a pre-treatment. Value are expressed as mean \pm SEM $(\mathrm{n}=6)$, Significant difference at $P<0.05$ (ANOVA followed by Dunnett's test) compared with normal control and ulcer control group, MDA, Malondialdehyde; SOD, superoxide dismutase; CAT, catalase; GSH, reduced glutathione; GPx, glutathione peroxidase; GST, glutathione transferase; " significant when compared to the ulcer control groups (1 and 2); ${ }^{*}$ significant when compared to the reference control group (3).

enzymes GPx and GST and/or renders these enzymes inactive and/or less active [58].

\section{Conclusion}

It may be concluded that a single oral administration of essential oil from Thymys algeriensis possesses a significant gastroprotective effect as assessed by significant antioxidant activity as it attenuated the level of TBARS and elevated levels of GSH, GST, GPx, CAT and SOD. This effect could be related to an increase of gastric mucosal defensive mechanisms. The effectiveness of the essential oil and its low toxicity requires further study to elucidate the action mechanism as well as to isolate the gastroprotective principles. In addition, the histopathological results of our study revealed that treatment with EOTa (117 and $180 \mathrm{mg} / \mathrm{kg}$ ) resulted in maintaining the mucosal integrity and a mild mucosal ulceration.

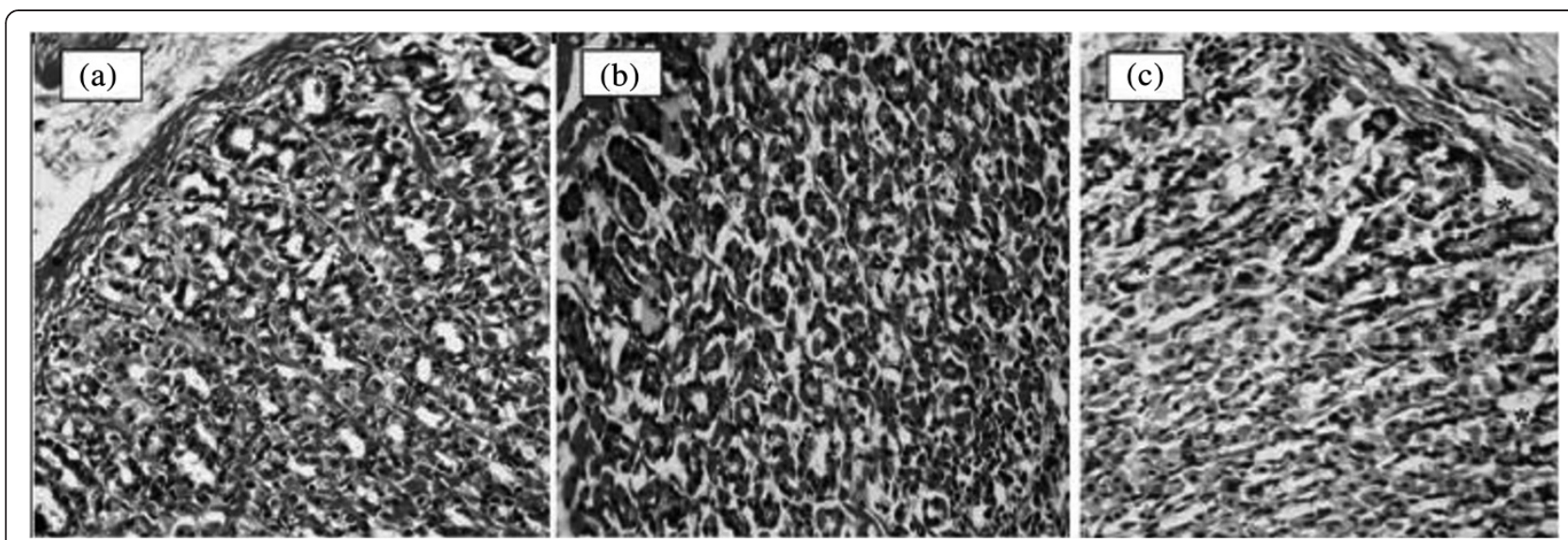

Figure 6 Photomicrography of histological sections of stomach lesions produced by $\mathrm{HCl} / \mathrm{ETOH}$ in male and female rats. Note the secretion inside of glands $\left(^{*}\right)$ in treated group with EOTa. Female rat $(117 \mathrm{mg} / \mathrm{kg})(\mathbf{a})$, male rat $(180 \mathrm{mg} / \mathrm{kg})(\mathbf{b})$ and female rat $(54 \mathrm{mg} / \mathrm{kg})$ (c). Microscopy magnification $40 \times$ 


\section{Competing interests}

The authors declare that they have no competing interests.

\section{Authors' contributions}

GF, BAM, BT and TW participated in the design of the study and performed the statistical analysis. GF and BAM kept rats and carried out the animal experiment. GF was involved in drafting the manuscript and revising it critically for important intellectual content, LA gave final approval of the version to be published. All authors read and approved the final manuscript.

\section{Acknowledgments}

This work was supported by the Tunisian Ministry of Higher Education, Scientific Research and Technology "Enseignement Supérieur, Recherche Scientifique et Technologie". The authors would like to express their utmost gratitude and appreciation to Dr. Chokri Messaoud (INSAT) for his help in the GC/MS analyses, Mr. Hamdi Lazhar for identifying the plants and Dr. Houda Bellamine and Raowdha Smiti for performing the histological sections.

\section{Author details}

'Laboratory of Biochemistry and Molecular Biology, Faculty of Science of Bizerte, Bizerte, Tunisia. 'Laboratory of Biomonitoring of the Environment (LR01/ES14), Faculty of Sciences of Bizerte, Bizerte, Tunisia. ${ }^{3}$ Higher Institute of Technological Studies (ISET), Mogran, Zaghouan, Tunisia. ${ }^{4}$ Service of Anatomo- Pathology of Menzel Bourguiba, Bizerte, Tunisia.

Received: 26 May 2014 Accepted: 6 August 2014

Published: 26 August 2014

\section{References}

1. Guyton H: Textbook of medical physiology. Philadelphia 2000, 10:397-398.

2. Toma W, Hirumaluma CA, Guerrero RO, Souza-Brito ARM: Preliminary studies of Mammeam Americana L. (Guttiferae) bark/latex extract point to an effective antiulcer effect on gastriculcer model in mice. Phytomedicine 2005, 12:345-504.

3. Repetto MG, Llesuy SF: Antioxidant properties of natural compounds used in popular medicine for gastric ulcers. Braz J Med Biol Res 2002, 35:523-534.

4. Tuorkey M, Karolin K: Anti-ulcer activity of curcumin on experimental gastric ulcer in rats and its effect on oxidative stress/antioxidant, IL6 and enzyme activities. Biomed Environ Sci 2009, 22:488-495.

5. Sarma AD, Mallick AR, Ghosh AK: Free radicals and their role in different clinical conditions: an overview. Int J Pharm Sci Res 2010, 1(3):185-192.

6. Sen S, Chakraborty R, Sridhar C, Reddy YS, De B: Free radicals, antioxidants, diseases and phytomedicines: current status and future prospect. Int J Pharm Sci Rev Res 2010, 3(1):91-100.

7. Al-Howiriny T, Alsheikh A, Alqasoumi S, Al- Yahya M, ElTahir K, Rafatullah S: Protective effect of Origanum majorana L 'Marjoram' on various models of gastric mucosal injury in rats. Am J Chin Med 2009, 37:531-545.

8. Zanatta F, Gandolfi RB, Lemos M, Ticona JC, Gimenez A, Clasen BK Cechinel- Filho V, Andrade SF: Gastroprotective activity of alkaloid extract and 2-phenylquinoline obtained from the bark of Galipea longiflora Krause (Rutaceae). Chem Biol Interact 2009, 180:312-317.

9. Laine L, Takeuchi K, Tarnawski A: Gastric mucosal defence and cytoprotection: bench to bedside. Gastroenterol 2008, 135:41-60.

10. Jai MS, George S: Pharmacology of proton pump inhibitors. Curr Gastroenterol Rep 2008, 10(6):528-534.

11. Barocelli E, Chiavarini M, Ballabeni V, Barlocco D, Vianello P, Dal Piaz V, Impicciatore M: Study of the antisecretory and antiulcer mechanism of a new indenopirydazinone derivative in rats. Pharmacol Res 1997, 35 (5):487-492.

12. Laszlo F, Amani E, Varga CS, Laszlo FA: Influence of sex hormones on ethanol-induced gastric hemorrhagic erosions in rats. Acta Physiol Hung 1992, 80:289-292.

13. Zakieh K, Mohammad KH, Mohammad JZ, Abbas B: The effects of female sex steroids on gastric secretory responses of rat following traumatic brain injury. Iran J Basic Med Sci 2011, 14:231-239.

14. Axell T, Skoglund A: Chronic lip fissures. Prevalence, pathology and treatment. Int J Oral Maxillofac Surg 1981, 10:354-358.

15. Rupesh KM, Mohamed NK, Tamizh MT, Fasalu ROM, Satya KB: A review on medicinal plants for peptic ulcer. Der Pharm Lett 2011, 3(2):180-186.

16. Borrelli F, Izzo AA: The plant kingdom as a source of antiulcer remedies. Phytother Res 2000, 14:581-591.
17. Goel RK, Sai RK: Anti-ulcer drugs from indigenous source with Eumphasison musa spaientum, Tamrabhasma, Asparagus racemous and Zingiber officinale. Indian J Phram 2002, 34:100-110.

18. Ubaka MC, Ukwe VC, Okoye CT, Adibe OM: Investigation into the antiulcer activity of aqueous extract of Aspilla africana. AJPMS 2010, 2(2):40-43.

19. Laciar A, Ruiz ML, Flores RC, Saad JRA: Antibacterial and antioxidant activities of the essential oil of Artemisia echegarayi Hieron. (Asteraceae). Rev Argent Microbiol 2009, 41:226-231.

20. Aidi WW, Mhamdi B, Sriti J, Ben Jemia M, Ouchikh O, Hamdaoui G, Kchouk ME, Marzouk B: Antioxidant activities of the essential oils and methanol extracts from myrtle (Myrtus communis var. italica L.) leaf, stem and flower. Food Chem Toxicol 2010, 48:1362-1370.

21. Le Floc'h E: Contribution à une étude ethnobotanique de la flore tunisienne. In Edited by Ministère de l'Enseignement Supérieur et de la Recherche Scientifique. Imprimerie Officielle de la République Tunisienne; 1983:402p.

22. Zouari N, Fakhfakh N, Zouari S, Bougatef A, Neffati M, Ayadi MA: Chemical composition, angiotensin I-converting enzyme inhibitory, antioxidant and antimicrobial activities of essential oil of Tunisian Thymus algeriensis Boiss. et Reut. (Lamiaceae). Food Bioprod Process 2011, 89:257-265.

23. Jug P: N Yugoslavian Pharmacopoeia, Pharmacopoea Jugoslavica edition quarta, vol. no. I. Belgrade, Yugoslavia: National Institute for Health Protection; 1984:126-128.

24. Dashputre NL, Naikwade NS: Evaluation of anti-ulcer activity of methanolic extract of Abutilon indicum Linn leaves in experimental rats. Int J Pharm SC Drug Res 2011, 3(2):97-100.

25. Lowry OH, Rosenbrough NJ, Farr AL, Randall RJ: Protein measurement with folin-phenol reagent. J Biol Chem 1951, 193:265-275.

26. Sedlak J, Lindsay RH: Estimation of total, protein-bound, and nonprotein sulfhydryl groups in tissue with Ellman's reagent. Anal Biochem 1968, 25:192.

27. Marklund SL: Pyrogallol autooxidation. In Handbook of Methods for Oxygen Radical Research. Edited by Greenwald RA. Boca Raton, Florida: CRC Press; 1985:243-247.

28. Takahara S, Hamilton HB, Neel JV, Kobara TY, Ogura Y, Nishimura ET: Hypocatalasemia: a new genetic carrier state. J Clin Invest 1960, 39:610-619.

29. Habig WH, Pabst MJ, Jakoby WB: Glutathione s-transferase: the first enzymatic step in mercapturic acid formation. J Biol Chem 1974, 249:7130-7139.

30. Hafeman DG, Sunde RA, Hoekstra WG: Effect of dietary selenium and erythrocyte and liver glutathione peroxidise in the rat. J Nutr 1973, 104:580.

31. Ohkawa $\mathrm{H}$, Ohishi N, Yagi K: Assay for lipid peroxides in animal tissue by thiobarbituric acid reaction. Anal Biochem 1979, 95:351-358.

32. Manal MET, Muhammad SS, Hapipah MA, Mahmood AA, Siddig IA, Hamid AHA: Gastroprotective activities of Turnera diffusa Willd. ex Schult. revisited: role of Arbutin. J Ethnopharmacol 2012, 141:273-281.

33. Malone RA: Pharmacological approaches to natural products screening and evaluation. In New natural products and plant drugs with pharmacological, biological or therapeutical activity. Edited by Warner $\mathrm{H}$, Wolf P. Berlin: Springer-Verlag; 1977:24-53.

34. Ben El Hadj Ali I, Zaouali Y, Bejaoui A, Boussaid M: Variation of the chemical composition of essential oils in Tunisian populations of Thymus algeriensis Boiss. et Reut. (Lamiaceae) and implication for conservation. Chem Biodivers 2010, 7:1276-1289.

35. Zouari N, Ayadi I, Fakhfakh N, Rebai A, Zouari S: Variation of chemical composition of essential oils in wild populations of Thymus algeriensis Boiss. Et Reut., a North African endemic species. Lipids Health Dis 2012, 11:28.

36. Haslam E: Natural polyphenols (vegetable tannins) as drugs: possible modes of action. J Nat Prod 1996, 59:205-215.

37. Adams RP: Identification of Essential Oils Components by Gas Chromatography/ Mass Spectroscopy. Carol Stream, IL: Allured Publ; 1995:469.

38. Adams RP, Weyerstahl P: Cis- and trans-Sabinene hydrate: comparisons of quadrupole and ion trap mass spectra. Research letter. J Essent Oil Res 1992, 4:197-200.

39. Loomis TA, Hayes AW: Essentials of Toxicology. 4th edition. London: Academic Press Limited; 1996.

40. Shay JP, Komaov SA, Fels SS, Meranze D, Grunstein M, Simpler H: A simple method for the uniform production of gastric ulceration in the rat. Gastroenterol 1945, 5:43-61. 
41. Yassir M, Al Mulla HYM, Najim RA, Farjou IB: A new in vitro model for ethanol-induced gastric mucosal damage. Jpn J Pharmacol Toxicol Methods 1999, 41:167-172.

42. Kvietys PR, Beveleign T: Role of methrophils and xanthine oxidase derived radicals in methanol-induced injury. Gastroenterol 1990, 98:909-920.

43. Machowska A, Szlachcic A, Pawlik M, Brzozowski T, Konturek SJ, Pawlik WW The role of female and male sex homones in the healing process of preexisting lingual and gastric ulcerations. J Physiol Pharmacol 2004, 55:91-104.

44. Aguwa CN, Nwako SO: Preliminary studies of the root extracts of Nauclea latifolia Smith, for anti-ulcer properties. Nig J Pharm Sci 1988, 4:16-23.

45. Ibrahim IAA, Qader SW, Abdullah MA, Nimir AR, Abdelwahab SI, AL-Bayaty FH: Effect of Pithecellobium jiringa ethanol extract against ethanol-induced gastric mucosal injuries in Sprague Dawley rats. Molecules 2012, 17:2796-2811.

46. Bou-Abboud CF, Wayland H, Panlsen G, Guth PH: Microcirculatory stasis precedes tissue necrosis in ethanol-induced gastric mucosal injury in rat. Digest Dis Sci 1988, 33:872-877.

47. Kinoshita M, Kume E, Tamaki H: Roles of prostaglandins, nitric oxide and the capsaicin-sensitive sensory nerves in gastroprotection produced by ecabet sodium. J Pharm Exp Ther 1995, 275:494-501.

48. Ueda S, Yoshikawa T, Takahashi S: Role of free radicals and lipid peroxidation in gastric mucosal injury induced by ischemiareperfusion in rats. Scand J Gastroenterol 1989, 24:55-58.

49. Ribeiro M, Yoshida WB: Reperfusion injury after intestinal ischemia: pathophysiology and experimental models. J Vasc Bras 2005, 4:183-194.

50. Sachs G: The parietal cell as a therapeutic target. Scand I Gastroenterol Suppl 1986, 118:1-10.

51. Wallmark B: Omeprazole: mode of action and effect on acid secretion in animals. Scand J Gastroenterol Suppl 1989, 166:12-18.

52. Paul N, Maton MD: Omeprazole. Drug Ther 1991, 324(14):965-975.

53. Bonnes-Taourel D, Guerin MC, Torreilles J: Is malonialdehyde a valuable indicator of lipid peroxidation? Biochem Pharmacol 1992, 44:985-988.

54. Tandon R, Khanna HD, Dorababu M, Goel RK: Oxidative stress and antioxidants status in peptic ulcer and gastric carcinoma. Indian J Physiol Pharmacol 2004, 48(1):115-118.

55. La Casa C, Villegas I, Alarcón de la Lastra C, Motilva V, Martín Calero MJ: Evidence for protective and antioxidant properties of rutin, a natural flavone, against ethanol-induced gastric lesions. J Ethnopharmacol 2000, 71:45-53.

56. Meister A: New aspects of glutathione biochemistry and transport selective alteration of glutathione metabolism. Nutr Rev 1984, 42:397-400.

57. Mizui T, Douteuchi M: Effect of polyamines on acidified ethanol-induced gastric lesions in rats. Jpn J Pharmacol 1983, 33:934-945.

58. Fridovich l: The biology of oxygen radicals. Sci 1978, 201:875-880.

doi:10.1186/1476-511X-13-138

Cite this article as: Guesmi et al:: Effects of Thymus hirtus sp. algeriensis Boiss. et Reut. (Lamiaceae) essential oil on healing gastric ulcers according to sex. Lipids in Health and Disease 2014 13:138.

\section{Submit your next manuscript to BioMed Central and take full advantage of:}

- Convenient online submission

- Thorough peer review

- No space constraints or color figure charges

- Immediate publication on acceptance

- Inclusion in PubMed, CAS, Scopus and Google Scholar

- Research which is freely available for redistribution 